\title{
Birds, Wind and the Making of Wind-Power Landscapes in Southern France (Aude)
}

\author{
Author Posting. (c) 'Copyright Holder', 2010. \\ This is the author's version of the work. \\ It is posted here by permission of 'Copyright Holder' for personal use, not for redistribution. \\ The definitive version was published in \\ Landscape Research, Volume 35 Issue 2, April 2010. \\ doi:10.1080/01426390903557964 \\ (http://dx.doi.org/10.1080/01426390903557964)
}

\begin{abstract}
Alain Nadai ${ }^{1}$
CIRED - Centre International de Recherche sur l'Environnement et le Développement

Jardin Tropical

45 bis avenue de la Belle Gabrielle

94736 NOGENT-SUR-MARNE Cedex

E-mail : nadai@centre-cired.fr

Olivier Labussière

CIRED - Centre International de Recherche sur l'Environnement et le Développement Jardin Tropical

45 bis avenue de la Belle Gabrielle

94736 NOGENT-SUR-MARNE Cedex

E-mail : olivier.labussiere@ centre-cired.fr
\end{abstract}

\footnotetext{
${ }^{1}$ Corresponding author.
} 


\title{
Birds, Wind and the Making of Wind-Power Landscapes in Southern France (Aude)
}

\begin{abstract}
Landscape and birds are an important cause of blocking wind power projects. This paper investigates the question whether birds and wind power might be part of a same landscape and what type of landscape this could compose. We do so by following birds, birdwatchers and wind power developers in their attempt to compose such a landscape in the South of France. Our perspective focuses on the attachments that animals or landscape might develop or entice human to develop. We show that the process by which such a wind power landscape is composed engages birds into successive translations, which ultimately translate bird intelligence in composing with the wind into a quality of the landscape. As a result, such a landscape emerges from a net of relations and has a quality which is not necessarily visually readable: it is accountable to the entities which have been brought into representation through / for its making.
\end{abstract}

\section{Keywords}

Landscape - Planning - Affect - Wind Power - Birds - Aude 


\section{Introduction}

Landscape and birds are an important cause of blocking wind power projects in France and other countries (DGEMP, 2004; Thayer and Freeman, 1987; Bell and al. 2005; Warren et al., 2005). Attention has been aroused by bird killings, which was partly the fault of badly designed wind power parks (De Lucas et al., 2004; Barrios and Rodriguez, 2004). Yet, it should be no surprise that the wind dash led to birds, for birds rely on wind as their energy in order to fly. As far as France is concerned, green and bird watching organizations are engaged in wind power development, planning and policy (ADEME, 2004; LPO, 2007; BirdLife International, 2005) and they made birds become part of the making of new energy landscapes. "Creating wind power landscapes" is an expression used by French institutions so as to depart from protectionist approaches (ADEME \& Ministry of Environment, 2005). But the question whether wind power might be part of a landscape and what type of landscape it could compose is still open. Taking the department of Aude (Languedoc Roussillon, southern France) as a research field, we investigate that question by following birds, birdwatchers and wind power developers in their attempt to compose such landscapes in the south of France. We approach landscape through the logic of affect, that is to say, by following the way in which birds might come to share the wind with wind power (and vice versa) and the way in which emerging wind power landscapes and planning might succeed (or not succeed) in recomposing the relations between these parties.

In so doing, our approach has much in common with a revival of materialism (Whatmore, 2006) and forms part of an analytical strand which focuses on the attachments that animals or landscape might develop or entice human to develop so as to engage in more-than-human agency. Hinchliffe et al. (2005) have shown that animal species are not 'present' or 'absent' but engaged into a degree of existence that varies with our ability to recognize and describe these attachments. Taking the case of reindeer, Hayden Lorimer (2006) described how the observer, by following the dynamics of the herd, became sensitive to a new presence of the landscape. Jamie Lorimer (2007) has discussed the role of animal 'charisma', that is, an animal potential for affecting humans, in making people engaged in biodiversity conservation policies. Within this focus, the originality of our paper is to connect the issue of affect and animal agency to issues of landscape planning. Instead of approaching bird issues in term of protection (Coles et Taylor, 1993; Krewitt and Nitsch, 2003), following birds in the way we do, allows us to grasp the way in which planning might become open to the logic of a specific site.

After presenting our materials and method $(\S 1)$, we introduce Aude wind $(\S 2)$ and describe the development of a wind power project on the Plateau de Haute Guarrigue, located in the Parc Naturel Régional de la Narbonnaise (PNRN) (Aude) (§3). We first detail birds' influence on the siting of the turbines, and then describe the development of a new bird watching method which allowed the French bird-protection organization (the Ligue de Protection des Oiseaux / LPO) to make birds part of project development. Using this example, the fourth part ( $\$ 4)$ analyses the ways through which the LPO is engaged in French wind power policy and undertaking territorial planning with birds. The last part (\$5) discusses this planning experience.

\section{Method and materials}

Migration constantly confronts birds with new obstacles. It induces them to learn anew how to optimize their relation with the wind and the changing human inhabitation. A bird intelligence is undoubtedly active in composing their 'animal world' (Von Uexküll, 1957). There is a bird's way of being affected by changes and of affecting these changes (Lorimer J., 2008). Approaching wind power project development through birds calls for understanding how wind turbines might affect birds (and vice versa), under which conditions turbines might become part of the world of birds (and vice versa) and the way in which these conditions might potentially affect the siting of the project (and vice versa). Landscape is no longer approached according to pre-established forms or qualifications, environmental impact or nature conservation, but by experiencing bird confrontation with the new presence of turbines. Just as the carpenter follows wood undulation in splitting resistant beams (Simondon, 2005), so the genesis of a wind power landscape is achieved and followed according to wind variations made sensible by the bird relation to the wind.

This calls for a specific type of ethology. It implies, among other things, to adopt a distance to formal bird classifications, since these do not necessarily reflect the bird's way of interacting with turbines. We thus approach what Deleuze calls a typology of 'modes of existence' that underlies the greater similarity 'between an ox and a plough horse, than between a plough horse and a racehorse' because 'the racehorse and the plough horse neither have the same affects nor the same capacity to be affected; whereas the plough horse has common affects with the 
ox' (Deleuze, 2003, p. 167). To put it differently, and still referring to Deleuze terminology, an ethology of affect is required in order to 'organize the good meetings' and compose a renewed ethos (Deleuze, 2003, p. 161) 2 .

The literature about the role of affect is important and the use of the idea is polysemic (see Thrift, 2003 for a discussion). In this paper, we take from Deleuze a definition of affect inspired by his reading of Spinoza: 'By affect, I mean the body affections through which the body power of acting is increased or diminished ${ }^{3}$ (Ethics, III, def. 3; Deleuze, 2003, p. 69-70). This definition (or a close version of it) has already found application in the social sciences (Anderson, 2006; Lorimer J., 2008). It opens the question of the body to more than human entities by potentially including any relation of composition or re-composition ${ }^{4}$. It also implies a key distinction between affection and affect. Affection is akin to a body stimulus; it is the stimulus of a body by another body. The idea of affect points to the potential for a more-than-body viewpoint, to a collective agency that encompasses both affection and body. It implies a way of affecting and being affected in order to engage in and invent new (collective) modes of existence, a new ethos through new encounters, such as envisaged in the Deleuzian definition of an ethology of affects (cf. supra). A key dimension of this definition is that of experimentation, which brings with it potential, reciprocity and vulnerability. Affect opens the body to the exploration of a potential, in the sense of an unknown power of relating and acting that brings it into being ${ }^{5}$. Reciprocity and vulnerability mean that being affected also consists in affecting the other according to a gradient of power that is proper to the other. In turn, an association increasing my power of action might be detrimental to that of the other.

In our case study, the process that allows this ethology of affect to become perceptible and to be at the core of project development is is akin to a border zone (in Kohler's sense, 2002) between the field and the laboratory, whereby the landscape as a field, continuum and complex set of relations is turned into a labscape as a matrix of discrete 'facts'. Such a lab field border allows for a new type of network (site, wind, wind turbines, birds, wind power developers, bird watchers...) that translates affect into space and leads to the emergence of a new landscape. Reading this process calls for a 'constructive' approach (Latour 2003) to the landscape process. Inspired by science studies analysis of the production of scientific facts (e.g., Latour at al. 1986) and their extension to the analysis of (scientific) field work (Latour, 1999, Roth et al.1999; Lorimer J. 2008), we follow the work of project development and its links to the project 'site', directing the analysis towards the making of things. Given the statistical dimension of the methodology developed by LPO in the case under scrutiny, our approach (in §3) also draws upon Latour's analysis of Reviel Netz's work on the birth of Greek mathematics and the role of diagram representation in the construction of formal deduction and conviction (Latour, 2007).

Our work is based on written and graphic documents, field observation and face to face qualitative interviews ${ }^{7}$ (28), with state ministerial fields (e.g., environment, equipment, industry and energy); local mayors; pro- or anti- 'wind' NGOs; territorial organizations such as the PNRN; and wind power developers; private landscape firms or environmental experts engaged in the development of wind power projects. The interviews were conducted in two campaigns during the autumn of 2006 and the spring of 2007.

\section{Wind}

The Aude is located in the southwestern of France, along the Mediterranean seashore and north of the Spanish border. The PNRN covers the eastern part of Aude, including several massifs, including the well known Corbières Maritimes and a littoral plain with lakes (cf. fig 1). The windy Aude littoral is a major route for birds on their way from Africa to Europe during the spring (pre-breeding migration, flying north) and back during the fall (postbreeding migration, flying south). Bird watchers describe migration as being a rough experience for birds. Here, for instance, is a description of birds' migration in the Narbonnaise. Migrating corridors are mostly used by soaring (or gliding) birds such as black storks and big raptors. These birds rely on rising air currents to soar. They take advantage of the updrafts produced by the wind as it blows over hills and mountain ridges or make use of rising columns of warm air called "thermals". They absolutely avoid situations in which these currents are absent. As this

\footnotetext{
${ }^{2}$ Delueze defines this ethology of affect as follows: 'an Art, art of ethics itself: to organize the good encounters, to compose real-life relations, to form powers, to experiment' (Deleuze, 2003, p. 161; authors' translation ('un Art, art de l'Ethique elle-même: organiser les bonnes rencontres, composer les rapports vécus, former les puissances, expérimenter'). Following Deleuzian aesthetics, it is possible to conceive land-planning as the art of experimenting with new modes of life; see Labussière, 2007.

3 (Authors' translation) 'Par affects, j'entends les affections du corps par lesquelles la puissance d'agir de ce corps même est augmentée ou diminuée' (Ethique, III, def. 3; Deleuze, 2003, p. 69-70)

4 'with meat, I make my own flesh' (authors' translation)('avec de la viande, je fais de la chair à moi'), (Deleuze, 1981)

5 'nobody knows in advance the affect of which he/she is capable' (Deleuze, 2003, p. 168), 'what one fish is capable of is not what another fish is capable of' (Deleuze, 1980) (Authors' translation).

6 The 'constructive' notion of 'site' underpinning the analysis draws upon Nadaï (2007), in which it is defined as follows: 'The project work suspends the sedimented uses in order to allow for a recomposition of the place under a new spatiality. The site [first] defined as the place subjected to the work of the project, is thus [a temporary and] plastic state of the place which is the place in suspense of its uses'.

${ }^{7}$ Interviews were conducted in French and translated into English by the authors.
} 
is precisely the case of water areas such as the sea surface ${ }^{8}$ and the lakes, soaring birds look for land areas, warm plateaus or foothills to fly over. Using thermals and updrafts, they can gain the altitude that allows them to glide over water areas by simply loosing altitude. Their journey through the Narbonnaise is thus made up of a succession of upward loops and glidings across waters.

As far as birds are concerned, winds are of two major types in the Aude, inducing two different configurations of the migration corridor. The "Marin" (the east-wind from the sea) pushes the migrating birds towards the west, towards the land and the Corbières massif, so that on east-wind days migration extends into the territory and turns into a loose and diffuse migratory corridor. The second type of wind, the "Cers" or "Tramontagne" (the north-west wind, dominant, especially in spring), pushes the birds east, towards the coast, where they must fight so as not to be blown off course over the sea. On Tramontagne days, the migratory corridor is restricted to a few kilometres between the coast line and the Corbières foothills: birds fly against the wind at a very low altitude and do their best to avoid water areas. According to bird watchers, migration in the Narbonnaise is quantitatively impressive. About 40,000 raptors (19 species), 1500 storks ( 2 species) and 1,000,000 passerines pass through every year, making the area into a unique place for bird watching in Europe.

Bird watching and scientific ornithology have developed a complex relation by which the former has long been confined to "amateur" practice (e.g., Barrow et al. 2007 for an historical analysis of this relation in the US). Networking and the assertion of the affective dimension in amateur involvement with animals have been pointed to as part of this moving frontier (Charvollin et al., 2007; Despretz, 2007). Bird watchers' love for field work and affective commitment are important parts of their engagement in bird watching ${ }^{9}$. Far from implementing readymade classificatory principles, bird identification relies on a kind of snap recognition, based on a familiarity with bird species and on the perceptual experience of their character (Mac Donald, 2002). Central to the observer figure is the ability of autodidacts perceptively and quickly to identify a bird (no books are taken into field) and make notes, and the practice of increasingly separating the moment of observation from that of the confrontation with the model (bird classification and guides). As has been shown (Lynch et al. 1999; Waterton, 2003), classifications or field guides do not provide a strict rule for implementation but rather a framework in which to perform identification. The 'jizz', ${ }^{10}$, which points to a 'character rather than characteristics' that any animate or inanimate object might possess, to 'something definite yet indescribable', is part of the chain allowing bird identification. It is also part of what has been called the 'affective charisma' of birds in order to underline the active and affective dimension of the relation that birds might entice birdwatchers to engage in (Lorimer J., 2007).

Two bird watching spots are famous in the Narbonnaise area: the plateau de Leucate (spring, pre-breeding migration) and the massif de la Clape (autumn, post-breeding migration) (cf. fig. 1). Quantifying species in a migration survey (i.e., number of birds, number of species, spot) was the use until wind power came into the picture and raised new issues by pointing to bird reaction to the turbines. 'Bird reaction is something new ${ }^{11}$. Some birds visibly don't understand how to get away with the situation [...] I remember a group of black storks: we saw that they were trying to soar, but the weather didn't permit it. They were constantly beat down by the wind. They were flying towards the turbines; they then felt they couldn't make it and made a U-turn. They did so again and again. When you see this, you tell yourself there's something wrong with the situation. Usually, a migratory bird keeps on flying, ${ }^{12}$. This scene illustrates the extent to which Georges, a trained bird watcher, who decided to live in the Narbonnaise 'because the black storks were flying by', is affected by the experience of this group of storks faced by the turbines. In order to note this experience and become affected by it, Georges needed to learn how to follow the birds in their trajectory and successive decisions. This is what he means when he says that bird reaction is 'something new'. It is new for him because it calls for new methods of observation. Interestingly, such an innovation overlaps with the way in which developers approach wind power issues.

For developers, wind power siting is primarily driven by energy considerations. The average wind in the PNRN is stronger than $7 \mathrm{~m} / \mathrm{s}$ and qualifies the Aude as one of the most attractive regions for wind power in Europe. By the autumn of 2007, 10 parks were in place (92 Turbines), amounting to 110, 2 MW in the sole PNRN. The department has been among the first French departments to develop wind power parks ${ }^{13}$. While the first parks have most often been sited regardless of bird protection areas (Cambrony 2003), recent wind power schemes attempted to regulate the 'wind dash' (Région Languedoc Roussillon, 2003; Préfecture de l'Aude, 2005; PNRN de la Narbonnaise, 2003).

\footnotetext{
${ }^{8}$ Horizontal (rolling) thermals are present over the surface of the sea, but gulls are the only birds able to use them for gliding. Raptors and storks only use vertical thermals.

${ }^{9}$ The French LPO's current Sauvegarder Observer S'engager 2007 advertisement is reminiscent of this, showing three different figures of engagement in bird protection: protection, observation, engagement. http://www.lpo.fr/adhesion/sos/index.html, consulted November 19 , 2007.

10 The etymology of "jizz" is disputed, but one assumption traces it back to the GISS, meaning the "General Impression of Shape and Size of a Plane', an acronym used by the Second World War aircraft spotters (MacDonald, 2002).

${ }^{11}$ Emphasis by the authors.

12 Interview with Georges, ornithologist, former LPO staff.

13 Piecemeal projects were set up throughout the 1990s before sustained development came with the implementation of fixed tariffs for wind power electricity in 2000. As of 2003, few wind parks were in place (8 parks / 59 Turbines / 43, $3 \mathrm{MW}$ ).
} 
The PNRN scheme was devised in three steps, including a concerted choice (communities, experts, NG0's, State representatives) of favourable zones for wind power development ${ }^{14}$. Except for littoral communities living from tourism, most communities in the area are willing to develop wind power in order to increase their municipal budget $^{15}$. In this context, the PNRN scheme is aimed at delimiting zones that could be equipped with wind parks the so-called wind power 'envelopes' - and zones that should not. A charter completes the scheme, providing specific guidelines for each envelope (e.g., re-powering, extension, dismantlement). Local developers welcome this initiative as it reduces uncertainties in project development and 'makes the game clearer'. The way in which they approach the siting of the turbines might be summarized as follows.After passing through a turbine, the wind is stirred up. It needs space in order to recover speed and become a smooth flow again. Compromising between slipstream losses and space use is a way to maximize energy production. A rule of thumb is to leave approximately ten turbine-diameters between machines aligned 'in the wind' and three diameters between machines aligned perpendicular to the wind. In turn, energy considerations prescribe a type of flexible grid-like display that depends on the technical object (i.e., the type of turbine). Developers, then, 'compose with the rest [...], confronting technical criteria with [...] legal constraints, social and environmental criteria' (a local wind power developer) so as to maximize economic profit. Playing with site-related features so as to display turbines in an optimal way is a major dimension of project development.

We shall now turn to this issue by studying one particular 'wind power envelope', located between La Palme and Port-la-Nouvelle (envelope "7" in fig 1) and overlapping with four communities ${ }^{16}$ (La Palme, Port-la-Nouvelle, Roquefort-des-Corbières, Sigean).

\section{Sharing the Wind in La Palme-Sigean}

The Plateau de Garrigue Haute welcomed the first industrial wind power project in France and may welcome the first re-powering experience in the country. Wind power development started there in 1990 with the Port-LaNouvelle Park. In 2000, the park was extended with the Sigean Park, lining up ten turbines at an angle to the first park (cf. Fig 2, blue dots). Finally, the La Palme - Sigean project (still under administrative assessment at the time of writing) proposes dismantling the Port-la-Nouvelle Park and expanding the Sigean Park along new lines. Most importantly, the site is located within a major migration corridor, which makes this project a case in which birds become an important project adjuster.

\section{Re-powering as a window for re-siting}

The Port-La-Nouvelle turbines were installed in 1993. Their fifteen-year operating contract has recently ended (2008). This has opened the perspective of re-powering and the possibility of re-siting the turbines. It provided the PNRN with an excellent occasion 'for showing that it is possible to dismantle turbines and recompose the landscape in a different way' (PNRN). While the PNRN insisted on avoiding co-visibility with the littoral plain for reasons of tourism, it also noted that the densification of the current park 'could lead to a funnel effect with the Port-laNouvelle machines [perpendicular to the littoral]' (PNRN). Since the migratory corridor was parallel to the littoral (SSW-NNE), the PNRN laid down that the Port-la-Nouvelle line (5 turbines) should be dismantled and replaced with a new line parallel to the littoral and the Sigean Park. In addition, bird monitoring was recommended before and after project so as to follow the impact of re-powering on birds.

As witnessed by the impact study (EDF Energies Nouvelles et al., 2007), the developer followed the PNRN prescription. Yet the project went through a set of successive siting scenarios and the details of siting have largely been driven by bird issues. The presence of micro-corridors for migration imposed the alignment of new turbines with the existing turbines (cf. Fig. 2 and 3). These could then be dismantled and replaced by new and bigger turbines in order to get rid of the so-called 'funnel effect'. The final project includes 27 turbines, 2, $3 \mathrm{MW}$ each. Observation of pre- and post-breeding migrations led to a cartography of bird-flying paths. Figures 4 and 5 clearly show that the turbines are sited between the areas that birds most frequently fly through, so that it is clear that the bird issue has driven re-siting in La Palme Sigean. Yet as siting proceeds through spatial display, this raises the question about how space could be composed with birds, a question that we will now turn to examine.

\footnotetext{
${ }_{15}^{14}$ In 2006, this scheme became legally binding through its inclusion in a local Scheme of Territorial Coherency.

${ }_{15}$ According to a local mayor's estimate, the French wind power tax amounts to about 20,000 €/MW/year.

${ }^{16}$ French levels of governance do not overlap with the ones usually covered by the Anglo-Saxon terminology. For the sake of simplicity, we use a terminology found in international descriptions of the French administrative organization (OECD, 2006): 'Municipality(ies)' or 'community' refer to the French commune or municipalité, an entity more or less corresponding to the English parish or local government, although it is not a governmental administration in France; mayors or local councillors are their elected representative; 'department' refers to the French départment, a sub regional administrative division; 'region' refers to the French region; 'ministerial fields services' refers to the regional or departmental administration.
} 


\section{A laboratory for micro-siting}

French wind power has induced the production of a tremendous amount of bird surveys as a component of impact studies. Yet only a part of these relies on usual bird watching methods. 'Behaviour observation' is part of what the LPO calls 'micro-siting' (LPO, 2007), referring by this term to a focus on the understanding of birds' reaction to a given site, eventually including the presence of turbines. It was devised by the LPO on the basis of 'what has been developed in Port-la-Nouvelle and [of] the international bibliography' (French LPO).It differs from usual migration surveys in that '[The] goal is not [...] a comprehensive account of migrating birds, but an observation of their behaviour when they approach the turbines' (LPO, 1997, 17). In 1997 and 2001, the Aude LPO undertook two decisive surveys that made the Plateau de Garrigue Haute into a laboratory for new bird watching methods (LPO, 1997, 2001). Micro-siting allows the LPO to compose space with birds by converting relations into other relations, so that the relation between birds and wind becomes part of the relation between developers and wind. In order to do so, micro-siting proceeds in three steps, which we call 'blending into', 'aggregating' and 'translating into space', and constructs a chain of reference along which the conversion can operate without loosing sight of its first motivation: the compatibility between birds and wind power.

\section{Blending into as a way of objectivising}

According to the LPO: 'Micro-siting is a method that is difficult to objectivise' (LPO). But what does objectivity term exactly mean for the LPO? Two difficulties are mentioned, which both relate to the material conditions for field-work observation.

Mapping a bird's trajectory consists in mentally projecting a 3D bird flight trajectory into a 2D trajectory on a map (cf. Table 1, figure 8 below) and in assessing its flight height in comparison with that of the turbine blades. The task is performed on-site with a binoculars, a spotting-scope (portable telescope), colour pens and paper sheets, some of them featuring a topographic mapping of the site, with turbines if they are present (as in fig. 8). As soon as a bird is 'contacted', meaning that it is spotted, '[birdwatchers] tick it on the map and then look at what it does'. The trajectory is drawn by hand on a map and a line is inscribed in a table on a paper sheet displaying the following observations: rank, hour, species, number of birds, place, flight height and some other comments. Both inscriptions (map trajectory and table line) are identified by a rank number and work as technologies of order (Roth at al., 1999): they allow the observers to reference the field-observation and to coordinate the progress of their field work. Up to forty contacts may be referenced in a day and displayed in several maps if necessary. As has been mentioned in the above, bird 'identification' relies on usual bird watching competences; it is underlain by a decisive affective dimension that allows for observation to be performed in situ (cf. supra references to Waterton, to Law and to Lorimer J. $)^{17}$. In the case under consideration, as the flight height is decisive for a bird faced by an operating turbine, the risk of parallax error is a key issue: 'what [is] difficult [is] to judge their height as they fly through the blades'. Various solutions have been devised in order to minimize this risk and tune into a bird's perspective. A first solution consists in saving attention by focusing on specific, most often protected, species (e.g., Golden Eagle, Red Kite). Another one is to post several observers and use the written / graphic documents to reach agreement among the observers on the results. This is done after field work, at the LPO office, and achieves a kind of third party viewpoint akin to that of the bird.

The Plateau de Haute Guarrigue provides a nice illustration of how the spatial position of ornithologists is ruled by birds, the wind, the topography or the configuration of the park in a manner that makes observers 'blend into' the site. In 1997, there was only one observation spot located on a culminating point, which depended on whether birds were migrating north (spring) or south (autumn). As of 2001, a new and perpendicular line of turbines had been added, which transformed the park into a non-linear design. Two bird watchers were thus posted before and under the turbines, working with walkie-talkies so as to follow birds throughout the park. In all cases, bird watchers were clearly considered as part of the protocol. They were represented (cf. Fig 6) and calibrated as such. Even their position, hidden behind a bush so as to blend into the site and not frighten the birds, is illustrated by a photograph that was made part of the description of the protocol (LPO 2001, p15-19). In other words, "micro-siting" assembles birds, birdwatchers, turbines and the site through a focus of attention, ex-ante training, ex-post agreement and observers display. It provides the conditions for a bird's behaviour to become perceptible and to be translated into textual and visual representations. While protected species are listed, they are mostly approached at this stage through 'contacts' (lines in the tables on paper sheets), that is, through individuals and individual trajectories. In such a protocol, objectivity amounts to blending into the situation so as to achieve a bird's point of view.

\footnotetext{
17 Jamie Lorimer provides a very sound analysis of these dimensions. His analysis of bird 'charisma' in relation to biodiversity protection in the UK (2006) includes a general description of the affective dimension (epiphany, jouissance) and competence underlying bird watchers' engagement. His analysis of corncrakes counting in the UK (Lorimer J., 2006) provides an in-depth analysis of the way in which such competence and affectivity are specifically performed in a given case and situation, for instance, by customising 'good practices' and tuning into the bird (developing a nocturnal sonic landscape familiarity, re-organising one's body in order to hear all-around) (Lorimer J. 2008). We do not immerse ourselves into similar aspects in this paper. We underline the spatial dimension and the topology of the observing assemblage, which includes the wind turbines.
} 


\section{Aggregating as a way of convincing}

The evolution of the Port-la-Nouvelle surveys between 1997 and 2001 bear witness to an evolution of the method that paved the way for quantification and provided the LPO with persuasive results in negotiations with developers. The 1997 survey had already derived quantifications from the described methods. Bird 'strategies' ${ }^{18}$ were classified into four categories. Birds could (1) fly over; (2) dive in (fly through below the blades); (3) make route to the east or (4) make route to the west. Proportions and percentages led to generic descriptions relating to the type of flight (soaring, flapping, others) or to species. Categories of an ethology of affect were already derived. It was, for instance, concluded that most soaring birds perceived the presence of the turbines and reacted in anticipation more than 500 meters ahead of them. Changes in trajectory mostly consisted in bifurcation, whose direction depended on the topography - i.e., whether birds were flying north (spring) or south (autumn) as the Plateau presented a different topography in each direction. Bifurcation to the east was exceptional, as birds did their best not to be blown off course to the sea. 'Flying over' or 'diving in or passing through' the turbines were rather exceptional strategies, undertaken only by what was called 'skilled gliding birds' (sic) such as the European honey buzzard (Pernis apivorus) or the red kite (Milvus milvus). Additional observations, especially in relation to topography, clearly attested to the fine-grained understanding of birds' reactions to the site. The 2001 survey set an enriched framework for classification in which space, turbines, behaviours and birds were codified as presented in Table 1 and fig 7 to 9 . The important number of observations (4487 birds, 1088 flights, 220 hours of observations) allowed the authors of this survey to use genuine statistical variables through cross variable percentages and significance statistical tests ${ }^{19}$, which translated individual / small group reactions into families / species behaviours.

Most important in this evolution is the way in which aggregation was gained and its consequence as to how the site and birds became present in the process. Very interestingly, aggregation was justified by the very necessity of protecting birds: 'Some species migrate individually, whereas others migrate in groups. Thirty isolated birds, each independently crossing the line of turbines $[\ldots]$ do not have the same meaning as the same number of birds having the same behaviour collectively at once. However, from the point of view of bird protection, these situations are identical, each referring to thirty birds engaged in a risky situation ${ }^{20}[\ldots]$ Analyses mainly consist in deriving means and percentages by categories, sectors, status, species' (LPO 2001, p. 19). In other words, bird's social habits are acknowledged, but when it comes to bird protection a bird is a bird. Aggregation within status, families or species is justified by necessity. In so doing, the imperative of bird protection sets new relations between flows of representations. On the one hand, aggregating individualities allowed the LPO to derive descriptive indices of generic behaviours (e.g., species or families' strategies, collective behaviours [depending on the size of the group], perception of external movements) $)^{21}$, eventually connecting results with species and their protected status. On the other hand, the singularity of individual situations is translated into paradigmatic examples: a given flight number, featuring a particularly risky bird's trajectory drawn on a map, could be proposed as an illustration for risky situations (cf. Fig 8).

Overall, aggregation increases representativeness, since it translates individual fates into numbers that can be circulated and associated with the statutory power of protected species. It also results in a loss in affections, since we loose the way in which each individual is affected by its fellows, and develops strategies in relation to them: socialization, time and individual histories are partly erased. However, and this is very important for what follows, connection to affection is not completely lost, for paradigmatic examples can be traced to individual situations, if need be.

\section{Translating into space as a way of siting}

Adding birds up still does not compose space. The third step consists in translating paradigmatic strategies into space. Spatiality is constructed through bird behaviour by the means of two ideas: specific composition and microflying paths. Specific composition is the proportion of species in each sector that allows for a spatial differentiation of the site. It is a static translation of bird movements, emphasizing species presence and endowing space with the values already attached to species (e.g., protected species, Species of European Conservation Concern). Micro-flying paths are a fine-grained and spatially differentiated representation of the migration flow at the level of the site (cf. fig 9). It is an index of movement endowing space with generic density of use at a level that is relevant for a wind power developer. What is gained in this step is an exploration of spatial relations through quantification. Here again, what is discarded is somewhat conserved in another way, since the precedent step brought up an understanding of

\footnotetext{
${ }^{18}$ The terminology used here should be noted. 'Strategy' clearly endows birds with a capacity of anticipation, which in turn endows them with $a$ priori agency in the situation. By contrast, the idea of 'reaction', commonly used in 'scientific' psychology and ethology, has been questioned for its role in reducing animals conduct to non-intentional behaviours and in marking off academic science from so-called amateur observation (Despret V., 2007).

${ }^{19}$ Probability for the result obtained to be wrong.

${ }^{20}$ Emphasis by the authors.

${ }^{21}$ These and the immediately preceding descriptions are categories of an ethology of affects as described by Deleuze (Deleuze, 2003, p. 65, 167168).
} 
how birds are using the various sectors of the site (A, B and C). Three types of spatial relations were explored, all relating to the compatibility between birds and the turbines in the Plateau de Garrigue Haute.

A first category of results was site and class specific. It provided a measurement of birds' relation to the specific site of the Plateau de Garrigue Haute by aggregating behaviours according to bird classes. This, for instance, was the case in descriptions of the ways in which birds fly past the site: 'Storks mostly fly along the littoral [sector A] [...] Pigeons fly on each side of the Plateau through sectors A [west] and C [east]". Eventually, individual observations are required in order to enrich and make sense of these generic conclusions.

A second category of results reached beyond the specific case of the Plateau to point to birds' relational competence to external stimuli. One instance of such a result is the quantitative description concerning the reactivity and the agility of certain species that more successfully engage in flying-through strategies (e.g., barn swallows [Hirundo rustica], black kite [Milvus migrans]...) ${ }^{22}$ (LPO 2001, p33). Another instance is the assumption that the presence of an isolated soaring bird might constitute an attracting sign for fellow birds in search of height (LPO 2001, pp. 25 26). Overall, results of this type show that birds perceive turbines from far away and react to their presence by changing route. However, under unfavourable wind conditions, they might be blown off course to the vicinity of the turbines and opt for risky strategies such as 'flying over' or 'flying through'.

Last but not least, an important result related to generic considerations concerning the siting of turbines. Results showed that turbines lined up parallel to the migratory flow reduce birds' chances of having to engage in risky strategies (LPO 2001, p43). More specifically, it led to PNRN prescriptions for the re-siting (re-powering) of the turbines on the Plateau.

\section{Bird compatibility with wind power: a conditional ideal}

'The situation in Port-la-Nouvelle is very specific [...] when there is a northwest wind, birds are violently blown off course towards the sea [...] raptors and storks [...] once they're over the sea, they're had it [...]. They loose altitude, are forced to flap and work hard, which they are not made for, soon get exhausted and sink [...]. At the worst, if the wind is very strong, they stop and wait, hoping not to be blown off to the sea [...]. Faced by the park, [a bird] will have several choices: try to get past it by sheer effort, reducing its height of flight; changing route and flying round against the wind (to the west) or changing route by letting itself be blown off to the east. The problem is that this brings it over to the sea, so it will rather try to pass through the breach. The movement of a working turbine will entice the bird to avoid it by flying under it or to its side [...]. The current breach is sufficient for some species, but you also see groups of birds that split when approaching the Plateau [...]. In the end, turbines are not really bird choppers there, but the Port-la-Nouvelle park certainly entices reactions that aren't usual for birds flying by. We translate this by saying that there are 'energy losses' for the birds, but these losses are not at all quantifiable'. (Ornithologist, member of Aude-LPO)

This account, narrated from a bird's point of view, concludes that there is a compatibility between birds and turbines that is conditional upon siting. Its conclusion is both very general and local at the same time. On the one hand, it leads to the very general statement that developing wind power implies sharing wind (energy) between birds and humans. What was accepted as an unlimited, non-exhaustible and free energy now has to be shared. This new perspective on the issue opens a full spectrum of possibilities when compared with the 'bird chopper' story conveyed by many opponents to wind power. Yet as sharing wind is made tangible through micro-siting, the conclusion is also local. It is embedded in the site where it was produced and requires re-examination if it is to be exported to any other site. Why then, when so many efforts have been dedicated to derive formal relations from bird observations, are still enmeshed in the local? After all, the combination of table 1 and figures 7 to 9 adds up a technique for abstracting issues of birds and wind power. It is a diagrammatic representation of the site from which it became possible 1) to simplify the situation, 2) to derive an ideal set of relations so as to aggregate them and 3) to convert them into other relations. It is a representation that made it possible to convince developers and the PNRN, because relations between birds and turbines seemed to stem from it in the same unquestionable way as results stem from a mathematical proof, that is, logically, by formal deduction. Yet despite its deductive power, this diagram remains embedded in the situation. Even its formal appearance is fully underlain by the situation: breaching refers to this wind park, made up of two intersecting lines of turbines; 'A', 'B', 'C' sectors refer to the east-west divide structuring this situation in relation to the risk of being blown off course. Even the individual trajectories of birds are there, albeit sorted out and endowed with a general and representative value. As we have shown, blending into is at the origin of this diagrammatic representation: it provided it with its analytical power by allowing bird watchers to perceive bird strategies. But when it comes to planning wind power beyond the Plateau de Garrigue Haute, micrositing alone becomes limited because of its situated character. It does not therefore explain how the LPO could collaborate in wind power planning and policy at the national level. To do so, we have to take into account another dimension of LPO's work.

\footnotetext{
${ }^{22}$ Again, this shows that a passerine and a raptor can have much in common in the way they are affected by and cross a line of turbines.
} 


\section{Planning with birds: when the politics of birds meets wind power policy}

LPO engagement in French wind power development has gone beyond merely conducting bird surveys. Since the mid 1990s, the LPO has progressively articulated its politics of birds in connection with French wind power policy. The Aude branch of the LPO was the first to be aware of the rapid expansion of wind power and 'warned the national LPO, asking for support'. The 1997 and 2001 surveys on the Plateau de Garrigue Haute were benchmark experiences in this process. 2002 was a turning point, with the issuing of a LPO national position statement that was favourable to wind power provided its development be undertaken in accordance with biodiversity issues. The LPO also decided to become proactive towards planning and to help the administration, the private developers and the other environmental NGOs to grasp the wind power issue. This translated into a full range of actions, including a collaboration with the national (good practices for impact studies, ADEME et al., 2005) and the local administration in the assessment of wind power projects and the development of new bird watching methods (e.g., micro-siting).

LPO engagement in wind power planning progressively hinged upon a few principles. Anticipatory planning consists in collaborating with local administrations and PNRs in devising wind power schemes to which the LPO brings its ornithological knowledge as input. The goal is to help these actors develop a global grasp of their territory so as to avoid negative examples, such as wind power parks developed in highly sensitive areas (e.g., Special Protection Areas). Pre-diagnosis also became a major step in anticipatory planning. It consists in devising in-house territorial representations (mapping areas where the LPO does not wish wind power to be developed) from which early positions can be derive when the LPO is faced by the development of wind power projects: 'In any case, we advise them [...] to warn developers very early in the process, so that the latter don't invest in expensive surveys that make it difficult for them to back off'. In 2003, as a dash for wind followed the implementation of the French fixed tariffs, the Aude LPO became more vigilant towards the risks attached to massive development of industrial wind power. Its position was relayed by the national organization. Monitoring and law suits, that is, following wind power development and suing borderline projects in the administrative court in order to stop them, became the third strategic principle. This formed a third LPO strategy towards wind power planning.

Altogether, by integrating micro-siting with planning, this strategy allows micro-siting to go beyond siting without loosing its connection to the site. The full process by which this is achieved might be summed up as follows (cf. figure 10). Micro-siting allows the LPO to scale up through bird watching. As we have described, a new type of bird presence (individual or small group behaviour) is brought to the fore through micro-siting, which by individually following birds also makes the site perceptible as a wind power site. Aggregation then allows ornithologists to scale down by converting the multiplicity of individual / small group behaviours into generic forms of birds' presence. (families, classes or species), which are congruent with regulatory and planning categories. Spatial uses and frequentation (e.g., specific composition) are the way by which these aggregated forms of presence are translated into spatial categories such as sectors, micro-corridors, zones and areas. These spatial categories then influence the siting of the turbines. They are also included in LPO regional data bases and feed the 'in-house representations of the territory' that allow the local branches of the organisation to take stands in wind power development by the means of incentive ('anticipatory planning'/ 'pre-diagnosis') and threat (suing developers in the administrative court). By so doing, the LPO is developing a coherent planning activity and simultaneously 'maintaining' several types of bird presence and territory: the multiplicity of individual bird behaviours and the generic presence of registered / protected species; the multiplicity of the 'siting' territory and the unified/definite presence of the 'planning territory" 23 .

\section{Discussion}

Affect is probably the most innovating dimension of LPO wind power planning. By contrast to many wind power planning approaches based on protected zones and species (see, e.g., Nadaï \& Labussière, forthcoming), LPO planning attempts to re-compose classificatory categories in order to explore new compatibilities between birds and wind power. Yet this 'politics of affect' opens new possibilities without guaranteeing their reciprocal virtues ${ }^{24}$. The issue is all the more dramatic that it ultimately faces birds with rotating blades. To this extent, our case differs from others covered in the literature, which mainly deal with the way in which animals are translated into representation (institutional, scientific), but not so much with the feed-back effects these representations have on animal life (e.g., Campbell 2007, Roth et al. 1999). In turn, echoing a distinction between good and bad science put forward by philosophers of science (see, e.g., Latour, 2004), we shall question whether or not LPO planning approach is accountable to birds for the version of their ethos that it proposes. In other words: Does LPO planning approach offer the possibility for birds to be recalcitrant and 'dispute' the version of the ethos that it proposes? It is in the

\footnotetext{
${ }^{23}$ In this, our analysis is close to Albena Yaneva's analysis of the process of architectural design (Yaneva, 2005). Her case proceeded out of paper models, ours proceeds out of living entities.

${ }^{24}$ We do not mean that this is specific to the politics of affects. The politics of forms might also be concerned; by merely reproducing existing classifications, it does not offer possibilities of a new ethos that might be less detrimental to all parties.
} 
affect itself, as an affecting experience (opening to an unknown potential and allowing the parties to become different by engaging them into a shared experience), and in the way in which affect is brought to bear in the specific case under consideration, that we might look for an answer to this question.

The specific border zone and assemblage that we have described in this paper is held together by affects and is at the same time aimed at bringing affects into existence. It is very much attuned to the wind-related-kinetics of entities. Bird movements are at its core. So too are the movements of the turbines, which induce the emergence of a specific type of animal charisma ${ }^{25}$ in which velocity, agility or inertia become endowed with an affective dimension (the 'endangered' Black Stork or the 'skilled' Red Kite). Affect reaches well beyond the mere affections of one body by another body ('diving in', 'turning east', 'turning west'...). It enables the parties concerned to 'co-respond'26. It forms a channel through which observers can co-experience the ways in which birds are being affected by the turbines and make the turbines more 'ornithological'. Accountability is rooted in this shared experience. It conveys a quality that translates into the spatiality of wind power landscape.

The way in which the LPO translates these affections is decisive for for this to take place. It maps and encodes (through a number) individual trajectories / stories so as to bring them into textual and mathematical representation. We have pointed out two ruptures in this chain of reference. The first is the shift from individualities to quantities (from rows to columns in the spreadsheet) as the work passes from the field to the LPO office. This translation deletes key dimensions of the affections by erasing the influence of socialization and individuality (e.g., the role of a soaring bird in guiding it fellows towards thermals and updrafts). The second rupture is the shift from quantities to correlations. This turns affections into an attribute of bird classification so as to endow them with the force of conviction that formalism conveys (statistical significance). It detains movement (specific density) so as to differentiate space according to intensities of presence (micro-corridors). Although this turns affections into units, it does not lose the affect. Amazingly, the ultimate translation of affections is a rough and approximate graphic figuration (big arrows for the micro-corridors) that radically departs from the mathematical encoding which led to it. It aims at rendering the moving presence of birds. The result is that space is differentiated according to flowing intensities of wind usages, which still require the concerned entities in order to be fine tuned.

This has a direct impact on the way in which the siting of the turbines can ultimately be achieved. For instance, as was demonstrated by another (more advanced) project, birds were recalled through repeated negotiations between the LPO and the developer in order to adjust the siting: '[...] this allowed us to see that birds ... when they fly back in autumn... they cut like this (pointing with his finger on a map) [...] some of them slog their guts out to get away with the situation [...] which means that this siting [based on spring migration results] is no good [...] Therefore they [the LPO] said, 'Your turbines near the cliff won't work, you have to place them inside the plateau', which we did [...] so that migrating birds could cut as they now do. This resulted in the curvilinear shape that you see here in the north part of the park ${ }^{27}$. Clearly, affect, meaning here the bird's viewpoint, plays a decisive role in fine tuning the project described by the developer. Adjusting a project in such a way proves that the zoning displayed by graphic representations (of the type of fig 4 or 5) has no value but to call up the living presence of birds, and so to make planning accountable to them. While the LPO methodology might seem technically somewhat coarse by comparison with other animal geography surveys (e.g., Campbell 2007), its main quality is to give primacy to accountability over representation while not denying the role the latter can play. Such accountability is even reinforced by the monitoring of wind parks after siting and the LPO's legal opposition to projects that do not seem accountable to birds.

\section{Conclusion}

This paper is interested in the transformation of landscape that has occurred in the context of the energy transition. Taking a view that is intermediary between protection and planning, we questioned the possibility of compatibilities among such heterogeneous beings as wind, birds, bird protection organisation, wind power developers, and site. Our case study shows that the process by which such compatibilities are composed engages birds in successive translations, making them shuttle between the formal and pre-formal registers ${ }^{28}$ (affected entity, statistical class,

\footnotetext{
${ }^{25}$ We borrow this notion to Jamie Lorimer, who develops it in order to capture the way in which non-human entities might influence their perception and subsequent evaluation by human beings: 'Nonhuman charisma can best be defined as the distinguishing properties of a non- human entity or process that determine its perception by humans and its subsequent evaluation. In contrast to earlier understandings, in which charisma was understood as an innate, god-given property, I will here outline a more relational approach. Nonhuman charisma emerges in relation to the parameters of different technologically enabled, but still corporeally constrained, human bodies, inhabiting different cultural contexts'. Lorimer J. 2007, pp. 915

${ }^{26}$ We borrow the expression from Bruno Latour (Latour, 2008).

${ }^{27}$ Interview with a wind power developer, April 10, 2008.

${ }^{28}$ In so doing, this analysis works its way in between representational and non-representational strands of landscape theory (Wylie, 2007).
} 
geographical data). These successive translations build up a chain of reference that ultimately translates relations with the wind into a quality of the landscape. Thus wind power landscape emerges from a net of relations and owes its quality to the affects that underlie these relations. As we have shown, the assemblage at work pulls heterogeneous beings into a shared experience that radically changes their viewpoint and makes this process / landscape accountable to the entities which have been brought into representation through / for its construction. Accountability then points to a constant re-actualisation of relations to the wind, to their changing dynamics and their kinetic dimension. It becomes a core quality of this landscape, though not necessarily a visually readable one. It is a quality that enables these landscapes to evolve through time and reflect the sustainable dimension they are supposed to embody.

Beyond the specific case of wind power landscapes, the analysis points to the more general question of landscape quality and landscape theories. The question whether to evolve or preserve landscape quality is rendered acute in the face of the dramatic landscape changes that the current energy transition is bringing about (Cf. Selman, this issue $\mathrm{XX}$ ). Our case study suggests that this confronts us with the task of finding ways of bringing relations into a mode of existence that allows them to become the agent of their proper re-composition, ultimately reinventing the codes through which the concerned beings are associated in a landscape.

\section{References}

ADEME \& Ministry of Environment (2005) Guide de l'étude d'impact sur l'environnement des parcs éoliens (Paris : MEDD).

Anderson, B (2006) Becoming and being hopeful: towards a theory of affect. Environment and Planning D: Society and Space.; 24:733-752.

Barrios, L., Rodriguez A. (2004) Behavioural and environmental correlattes of soaring-bird mortality at on-shore wind turbines. Journal of Applied Ecology, 41, pp. 72-81.

Barrow, M. V., Tech, V. (2007) Coopération, conflit et contrôle: ornithologues et «birdwatchers» américains avant la seconde guerre mondiale, in : Charvollin, F., Micoud A., Nyhart, L. K. (Eds) Des sciences citoyennes? La question de l'amateur dans les sciences naturalistes, pp148-166, (La Tour d'Aigues, Aube).

Bell, D., Gray, T., Haggett, C. (2005) The "social" gap in wind farm siting decisions: explanations and policy responses. Environmental Politics, 14, pp. 406-477.

BirdLife International (2005) Position Statement on Wind Farms and Birds, Adopted by the BirdLife Birds and Habitats Directive Task Force on 9 December 2005.

Cambrony, M. (2003) Eolien et avifaune : les parcs éoliens des corbières et la migration des oiseaux. Colloque national, organisé par l'Institut Européen d'Ecologie et l'Association Multidisciplinaire des Biologistes de l'Environnement, "L'éolien en France: mythe et réalité », Metz, 12 février 2003. 17 p.

Charvollin, F., Micoud A., Nyhart L. K. (2007) La nature des profanes : pour une autre approche de l'amateur, in: Charvollin, F., Micoud A., Nyhart, L. K. (Eds) Des sciences citoyennes? La question de l'amateur dans les sciences naturalistes, pp 7-15, (La Tour d'Aigues, Aube).

Coles, R., Taylor J. (1993) Wind power and planning. The environmental impact of windfarms in UK. Land Use Policy, 10, pp. 205-226.

De Lucas, M., Janss, G., Ferre, M, (2004) The effects of a wind farm on birds in a migration point: the Strait of Gibraltar. Biodiversity and Conservation, 13, pp. 395-407.

Deleuze Gilles (1980) Cours de Vincennes sur Spinoza. Ontologie, éthique, décembre 1980. http://www.webdeleuze.com/php/texte.php?cle=188\&groupe=Spinoza\&langue=1

Deleuze Gilles (1981) Cours de Vincennes sur Spinoza. Immortalité et éternité, le 17 mars 1981. http://www.webdeleuze.com/php/texte.php?cle=188\&groupe=Spinoza\&langue=1

Deleuze, G. (2003) Spinoza. Philosophie pratique (Paris : Les Editions de Minuit, ed. orig. 1981).

Despret, V. (2007) L'affectivité au cœur des processus de professionnalisation. Le cas des Sciences du comportement animal, in: Charvollin, F., Micoud A., Nyhart, L. K. (Eds) Des sciences 
citoyennes? La question de l'amateur dans les sciences naturalistes, pp 56-73, (La Tour d'Aigues, Aube).

DGEMP (2004) L'éolien en France : une montée en puissance, DGEMP-DIDEME, juillet.

EDF Energies Nouvelles - La Compagnie du Vent (2007) Parc éolien de Corbières Méditerranée », Communes de La Palme et Roquefort-des-Corbières (11), Communauté de Communes de Corbières Méditerranée, Etude d'impact sur l'environnement, Février.

Hinchliffe S, Kearnes M, Degen M \& Whatmore, S (2005) 'Urban wild things - a cosmopolitical experiment', Environment and Planning D: Society and Space 23(5): 643-658

Kohler R.E (2002) "Landscapes and Labscapes : Exploring the Lab-Field border in Biology", U. of Chicago Press, pp 319.

Krewitt, W., Nitsch, J. (2003) The potential for electricity generation from on-shore wind energy under the constraints of nature conservation: a case study for two regions in Germany. Renewable energy, 28, pp. 1645-1655.

Labussière, O. (2007) Le défi esthétique en aménagement : vers une prospective du milieu. Le cas des lignes très haute tension (Lot) et des parcs éoliens (Aveyron et Aude) ; sous la dir. de Vincent Berdoulay: Thèse de doctorat: géographie et aménagement: Université de Pau et des Pays de l'Adour.

Latour B, Woolgar S, Salk J, 1986 Laboratory Life (Princeton University Press)

Latour B. 2008, "What the Style of Matters of Concern? - Nature at the Cross-Roads: the Bifurcation between Nature and its End", Van Gorcum, The Netherlands.

Latour, B. (1999) Pandora's Hope: Essays on the Reality of Science Studies (Cambridge, MA: Harvard University Press).

Latour, B. (2003) The promises of constructivism, in : Don Idhe (Ed) Chasing Technoscience: Matrix of materiality (Bloomington : Indiana University Press).

Latour, B. (2007) The Netz-Works of Greek Deductions, A review of Reviel Netz (2003) The Shaping of Deduction in Greek Mathematics: A Study in Cognitive History (Cambridge: Cambridge University Press), <URL http://www.bruno-latour.fr/articles/article/104-NETZ-SSofS.pdf

Lorimer, H. (2006) 'Herding memories of humans and animals' Environment and Planning D: Society and Space 24(4), 497-518

Lorimer, J (2007) 'Nonhuman charisma' Environment and Planning D: Society and Space, 25: 911-932

Lorimer, J (2008) Counting Corncrakes : 'The affective science of the UK Corncrake census'. Social Science Studies 38(3): 377-405.

LPO (1997) Suivi ornithologique du Parc éolien de Port-la-Nouvelle, Rapport Final, Geokos consultants.

LPO (2001) Suivi ornithologique des Parcs éoliens du plateau de Garrigue Haute (Aude), Rapport Final, Etude financée par l'ADEME.

LPO (2005) Protocoles de suivis pour l'étude des impacts d'un parc éolien sur l'avifaune.

LPO (2007) L'énergie éolienne et la conservation de la nature, Ligue de Protection des Oiseaux, Rochefort.

Lynch, Michael \& John Law (1999) 'Pictures, Texts, and Objects: The Literary Language Game of Bird watching', in M. Biagioli (ed.), The Science Studies Reader (London: Routledge): 317-41.

MacDonald, H (2002) '"What Makes You a Scientist is the Way You Look at Things": Ornithology and the Observer 1930-1955', Studies in History and Philosophy of Biological and Biomedical Sciences 33: 53-77. 
Nadaï, A. (2007) Site ou l'émergence d'un paysage. Cosmopolitiques, 15, pp.173-178. ${ }^{29}$

OECD (2006) Territorial Review of France (OECD publishing).

PNRN de la Narbonnaise (2003) Une charte de développement éolien pour la Narbonnaise.

Préfecture de l'Aude (2005) Plan de gestion des paysages de l'Aude vis-à-vis des projets éoliens.

Région Languedoc Roussillon (2003) Schéma régional éolien, 4 volumes.

Roth, WM \& G M Bowen (1999) 'Digitizing Lizards: The Topology of "Vision" in Ecological Fieldwork', Social Studies of Science 29(5): 719-64.

Selman, P. (forthcoming) Learning to Love the Landscapes of Carbon-Neutrality, Landscape Research.

Simondon, G. (2005) L'individuation à la lumière des notions de forme et d'information (Grenoble: Editions Jérôme Million).

Thayer, R.L., Freeman, C. (1987) Altamont: public perceptions of a wind energy landscape, Landscape and Urban Planning, 14, pp. 379-398.

Thrift, N. (2004) 'Intensities of feeling: towards a spatial politics of affect'. Geografiska Annale B, 86, pp. 57-78 .

Von Uexkull, Jacob (1957) 'A Stroll through the Worlds of Animals and Men', in C. Schiller (ed.), Instinctive Behavior (New York: International Universities Press).

Warren, C.R., Lumdsen, C., O’Dowd, S., Birnie, R. (2005) Green On Green : 'Public Perceptions of Wind Power in Scotland and Ireland'. Journal of Environmental Planning and Management, 48(6), pp. $853-875$.

Waterton, C (2003) 'Performing the Classification of Nature', Sociological Review 52: 111-29.

Whatmore Sarah (2006)'Materialist returns: practising cultural geography in and for a more-than-human world', Cultural Geographies, (13) 600-609.

Wylie, 2007. Landscape, Routledge / Key ideas in geography, 246 p.

Yaneva, A. (2005) Scaling up and down: extraction trials in architectural design. Social Studies of Science, 35, pp. 867-894.

\section{Acknowledgements}

The authors would like to thank two anonymous reviewers for their valuable insights. This work was undertaken with the financial support of the 'Conseil Français de l'Energie', the French Ministry for the Environment (MEDAD - Program PDD 'Paysage et Développement Durable'), the French Agency for the Environment and the Energy (ADEME) and the Region Ile-de-France (R2DS).

\footnotetext{
${ }^{29}$ For the unpublished English version of the paper: Nadai 2004, 'In the making of landscape: site', paper presented at the world conference of the Society for Social Studies of Science, Paris, Ecoles des Mines, Paris.
} 
Figure 1. Wind power envelopes, according the PNRN wind power Charter, from SYCOT, 2006

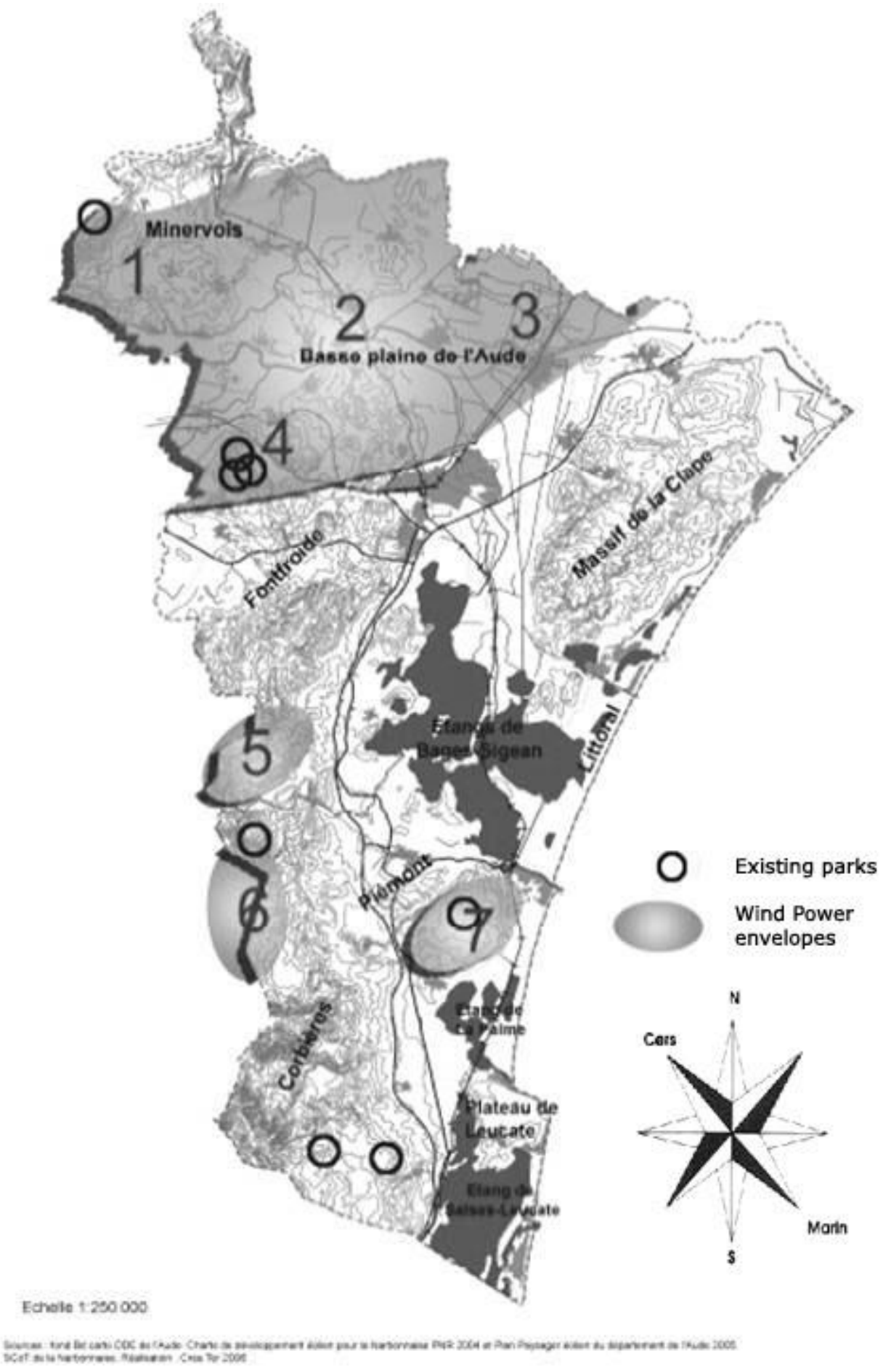


Figure 2: Final project - Phase 1 (2006), 13 turbines, 2,3 MW each. (Source: EDF-Energie Nouvelle, 2007) (Red: new turbines; blue: existing turbines)

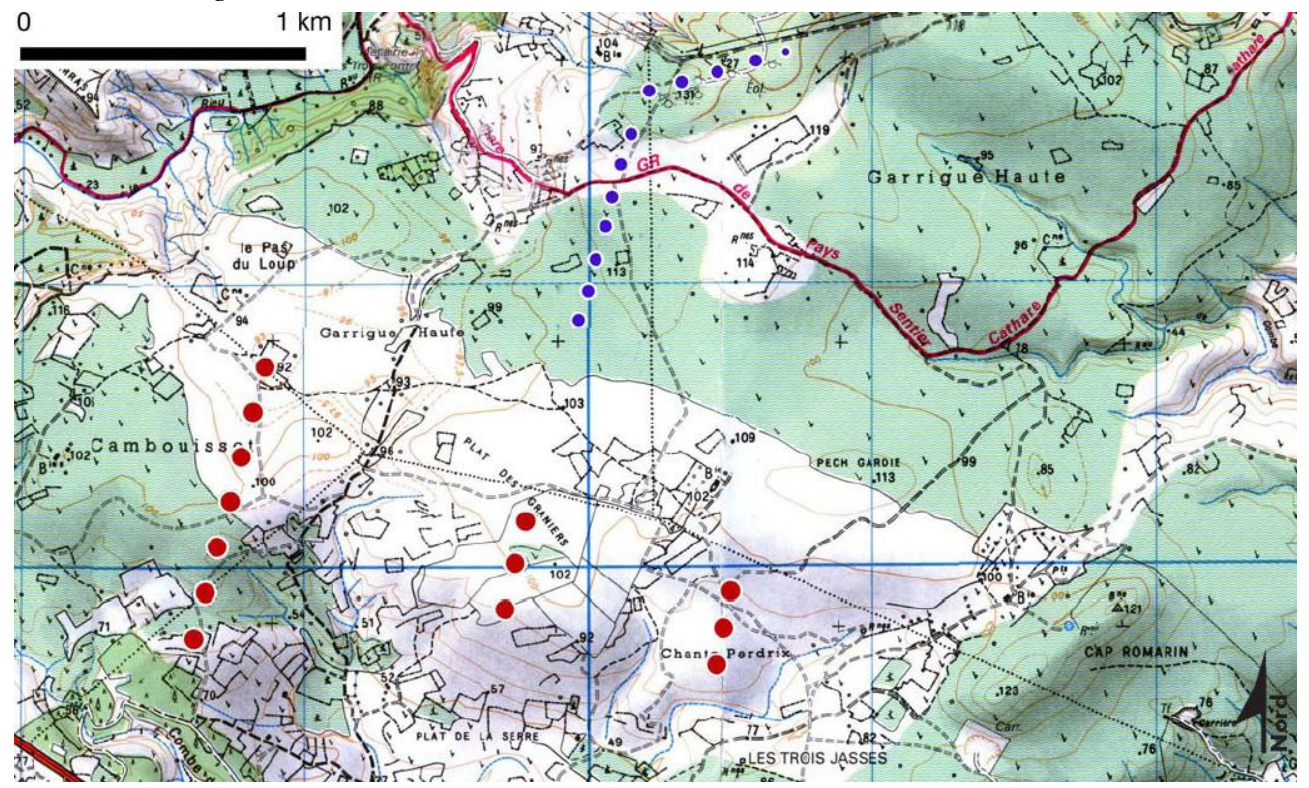

Figure 3: Final project, phase 2, 27 turbines, 2,3 MW each (Source: EDF-Energie Nouvelle, 2007) (Red: phase 1; yellow: phase 2)

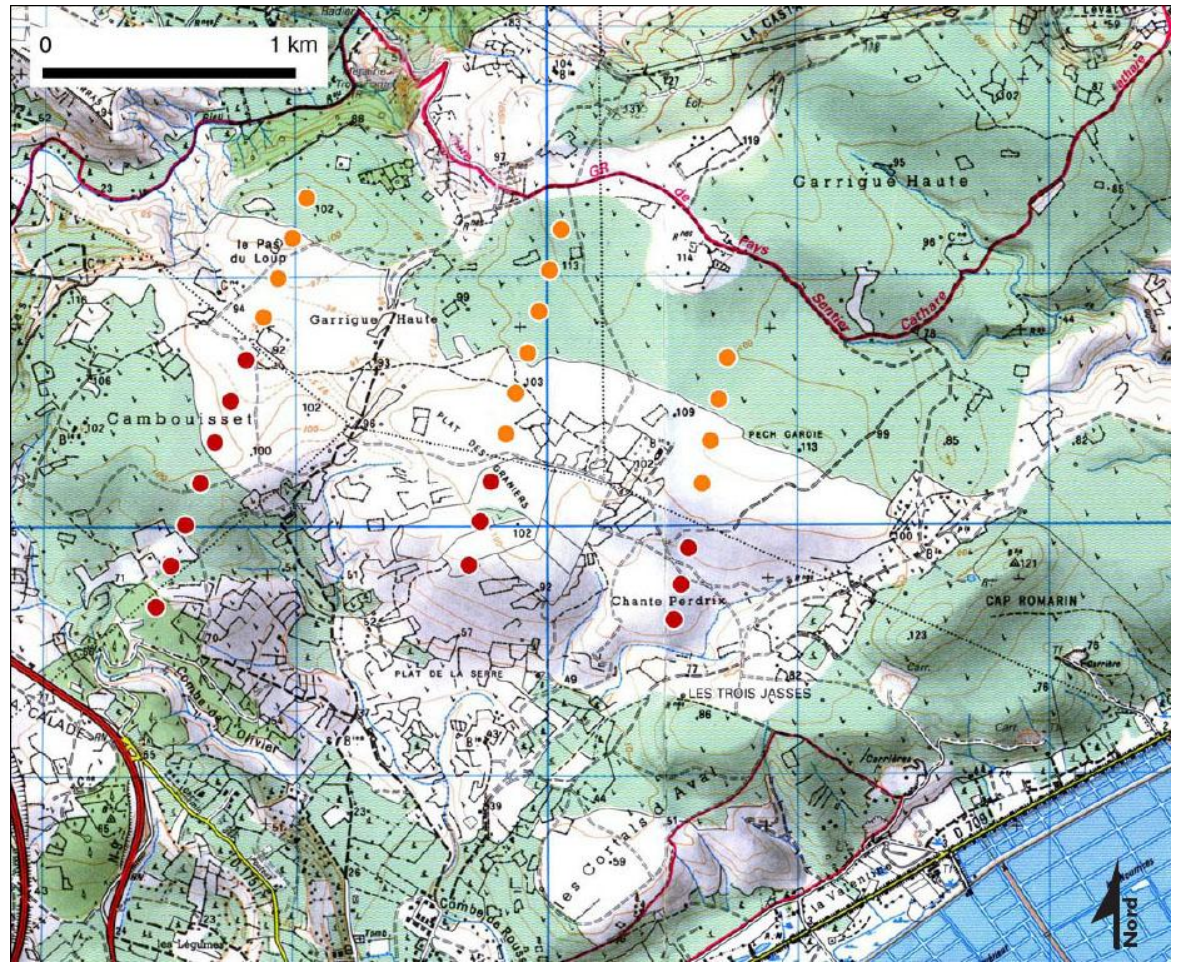


Figure 4: Pre-breeding mirgation, sensitive areas (blue: zones with high proportion of birds flying at blades height; red: zones with high density of migrating flights). Source: LPO Aude \& Abies (2005, 2006 a).

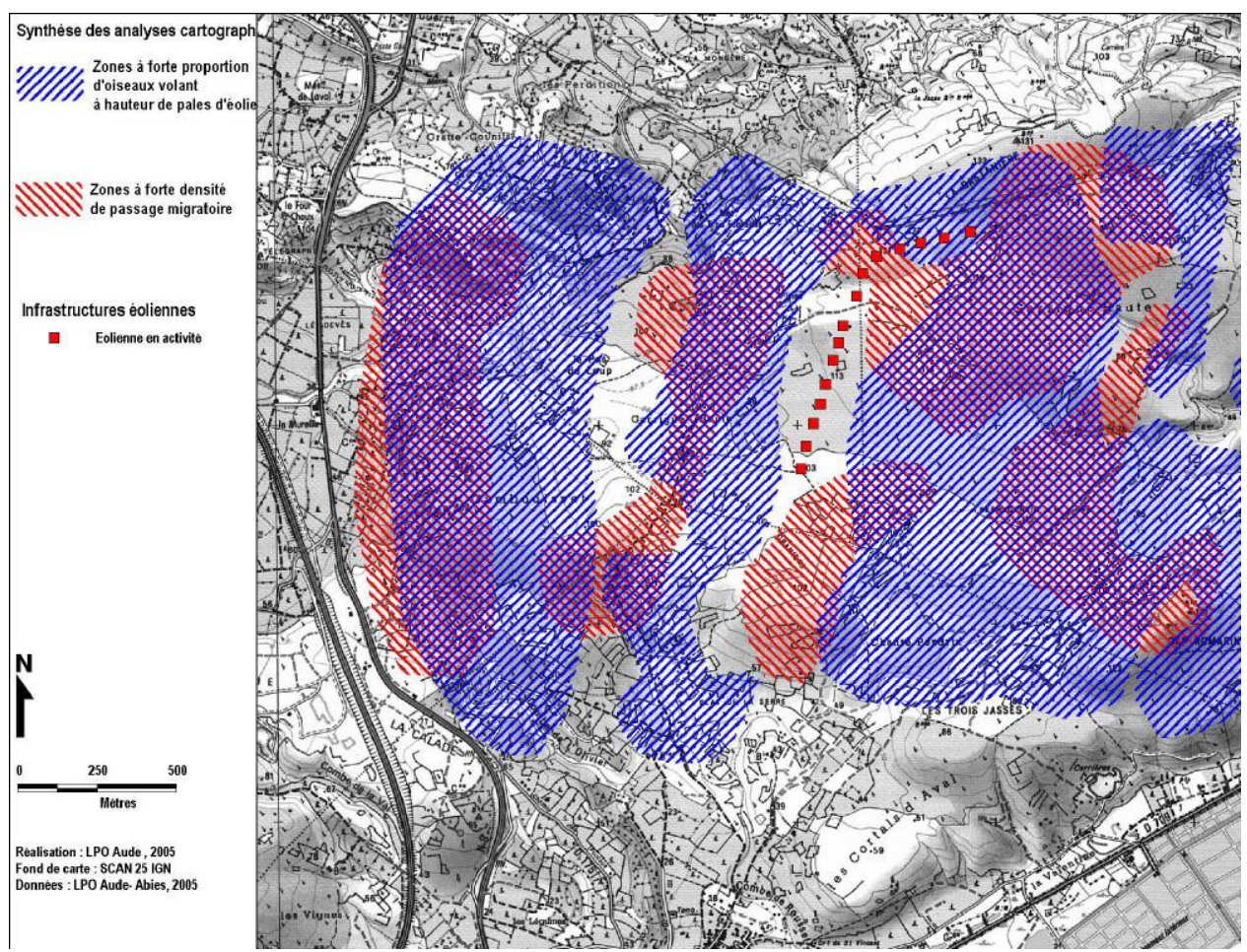

Figure 5: Post-breeding mirgation, sensitive areas (blue: zones with high proportion of birds flying at blades height; red: zones with high density of migrating flights). Source: LPO Aude \& Abies (2005, 2006 b).

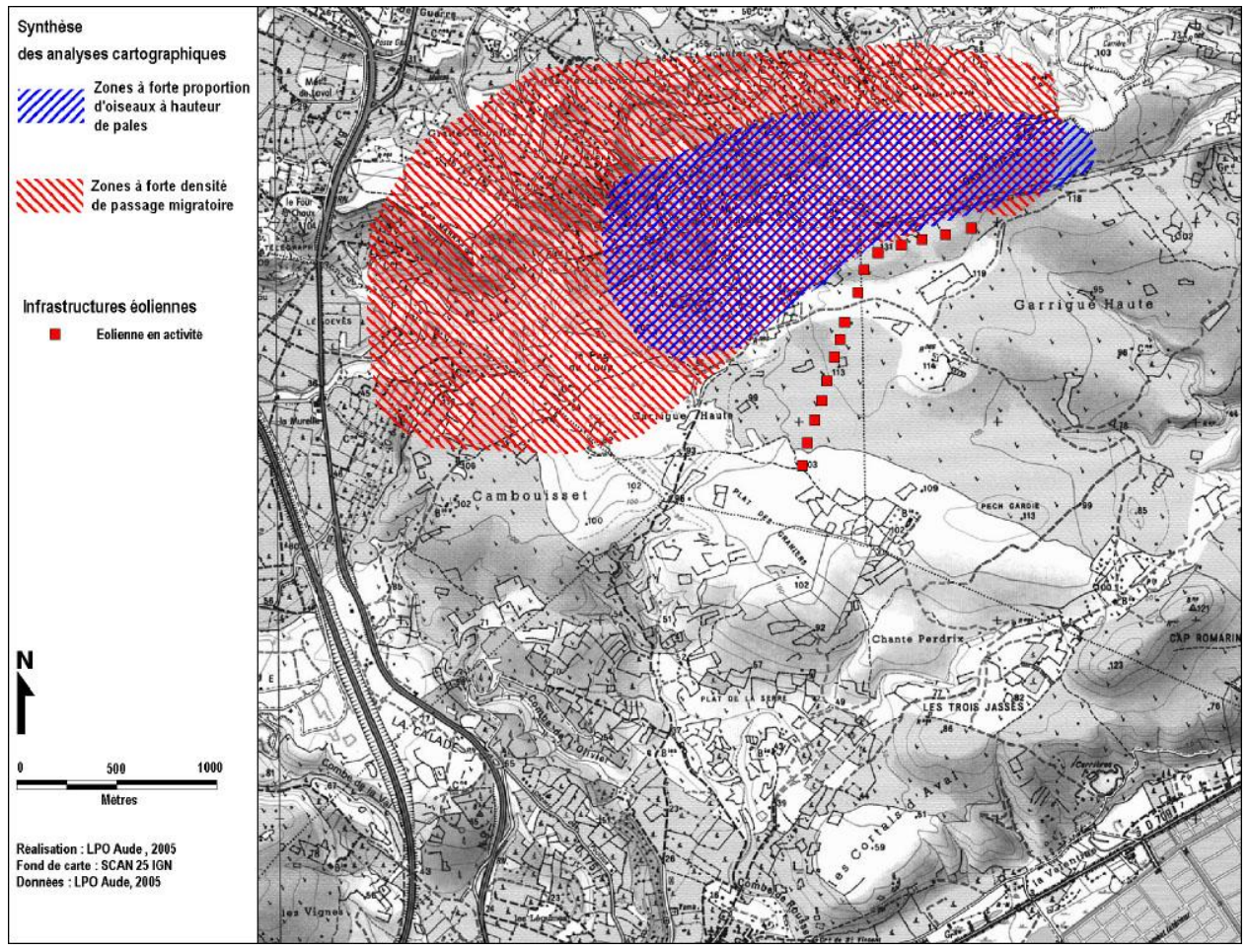


Figure 6: Bird watchers' representation and field of vision in the 2001 survey (Source: LPO, 2001)

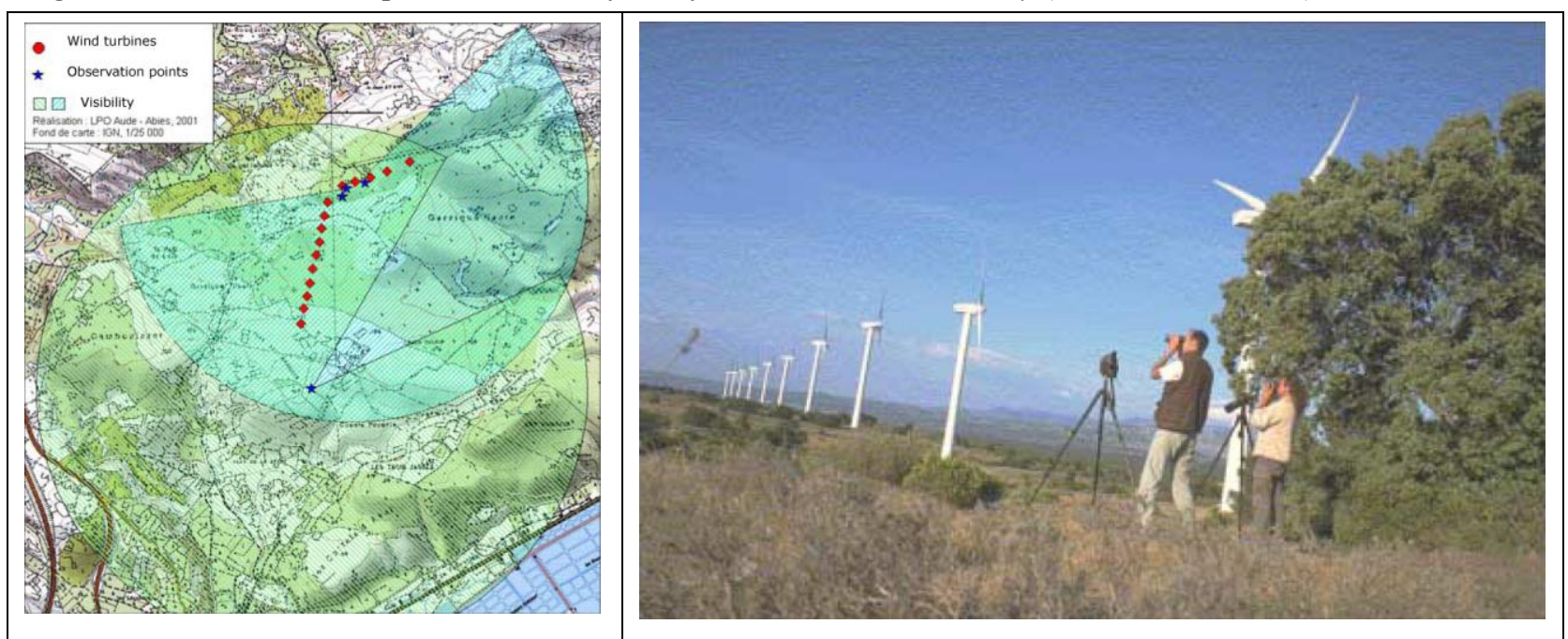


Table 1: Codification for behavior observation (LPO, LPO-Aude, 2001)

\begin{tabular}{|c|c|c|c|}
\hline Space & \multicolumn{2}{|l|}{ Behaviours } & $\begin{array}{l}\text { Birds } \\
\text { 'Status': M. Migrating birds; N. Nesting birds; I. } \\
\text { Undetermined. }\end{array}$ \\
\hline $\begin{array}{l}\text { Sectors } \\
\text { A: East of the plateau } \\
\text { towards the sea } \\
\text { B: Wind power area } \\
\text { C: West of the plateau } \\
\text { towards the foothills of the } \\
\text { Corbières } \\
\text { Turbines } \\
\text { A to E: Port-la-Nouvelle } \\
\text { turbines } \\
1 \text { to } 10 \text { : Sigean turbines }\end{array}$ & $\begin{array}{l}\text { Reaction to the } \\
\text { diving in (flying th } \\
\text { east; route to wes } \\
\text { breaching (flying } \\
\text { lines of turbines); } \\
\text { Anticipation dist } \\
\text { State of the turb }\end{array}$ & $\begin{array}{l}\text { eight }(1-15 \mathrm{~m}) ; 2 \text {. blades height } \\
\text { the blades }(70-500 \mathrm{~m}) ; 4 \text {. very } \\
\text { rk: flying over; flying through; } \\
\text { ugh, below the blades); route to } \\
\text { U-turn (dislocation of the group); } \\
\text { ugh the interval between the two } \\
\text { ther behaviours. } \\
\text { nce in meters } \\
\text { es: In / Out }\end{array}$ & $\begin{array}{l}\text { 'Families' (defined according to migration } \\
\text { mode, size, type of flight (gliding, flapped): } \\
\text { ducks, storks, shags, herons, gulls, passerines, } \\
\text { pigeons, raptors. }\end{array}$ \\
\hline $\begin{array}{l}\text { Figure 7: Birds reac } \\
\text { (Source: LPO 2001) }\end{array}$ & is to the park & 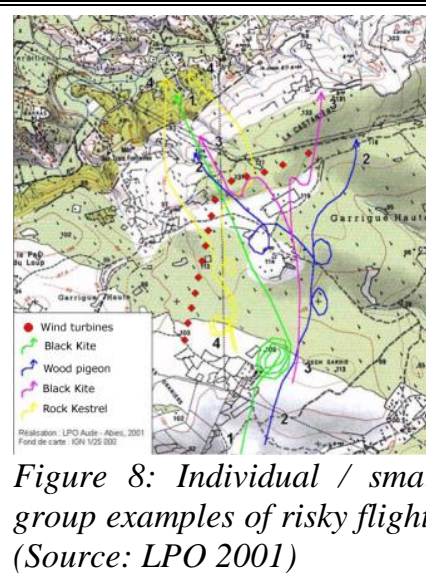 & $\begin{array}{l}\text { Figure 9: Micro flying-ways per sector } \\
\text { (Source: LPO 2001) }\end{array}$ \\
\hline
\end{tabular}


Figure 10: French LPO's engagement in French wind power policy

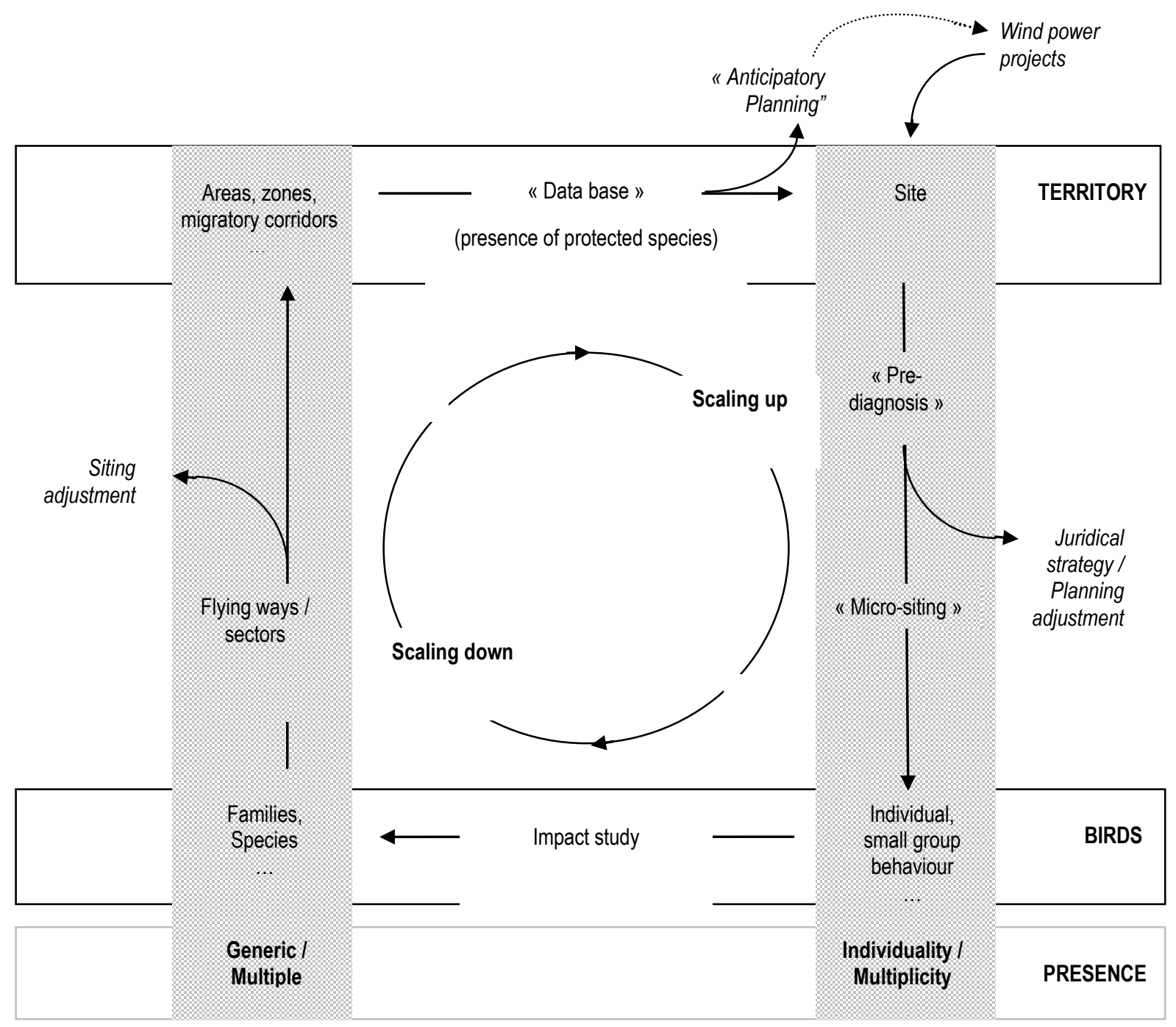

